podinsp. dr Grzegorz Gudzbeler ${ }^{1}$

podinsp. dr Mariusz Nepelski ${ }^{1}$

Przyjęty/Accepted/Принята: 31.10.2014;

Zrecenzowany/Reviewed/Рецензирована: 27.05.2015;

Opublikowany/Published/Опубликована: 30.06.2015;

\title{
Zintegrowana Platforma Symulacyjna Podmiotów Zarządzania Kryzysowego - spójne środowisko wirtualne ${ }^{2}$
}

\author{
An Integrated Simulation Platform for Organisations Engaged with Crisis Management \\ - a Coherent Virtual Environment
}

\author{
Интегрированная комплексная симуляционная система для субъектов \\ управления ЧС - единая виртуальная среда
}

\begin{abstract}
A BSTRAKT
Cel: Celem artykułu jest przedstawienie potrzeby integracji stosowanych w Polsce rozwiązań symulacyjnych wykorzystywanych do szkolenia kadr administracji publicznej w obszarze zarządzania kryzysowego, a szczególnie zakresu prac badawczo-rozwojowych dotyczących budowy zintegrowanej platformy symulacyjnej podmiotów zarządzania kryzysowego.

Wprowadzenie: Kompletne koncepcje budowy zintegrowanych komputerowych systemów wykorzystujących techniki symulacyjne - systemów służących do szkolenia funkcjonariuszy służb odpowiedzialnych za bezpieczeństwo z zastosowaniem technologicznie zaawansowanych trenażerów, to nie tylko fantazja, ale konkretna rzeczywistość i wymóg czasu. Zapoznanie się z ich zawartością pozwala na prawidłowe definiowanie wymagań i zrozumienie konsekwencji decyzji podejmowanych na etapie definiowania potrzeb. Stanowią one podstawowe kompendium wiedzy z tej dziedziny przydatne zwłaszcza dla podmiotów niezwiązanych na co dzień z symulacją, a planujących budowę podobnych systemów. Bardzo znaczące odniesienie do aspektu praktycznego tworzenia zintegrowanych systemów symulacyjnych stanowi o uniwersalizmie tego rozwiązania, które może być interesujące zarówno dla świata nauki i jego przedstawicieli pracujących nad różnymi aspektami symulatorów, jak i dla praktyków, którzy chcą szybko osiągnąć zamierzony efekt poprzez dobór dostępnych na rynku rozwiązań pośrednich.

Wyniki: W artykule została przedstawiona koncepcja funkcjonowania zintegrowanej platformy symulacyjnej podmiotów zarządzania kryzysowego z uwzględnieniem modułów umożliwiających wymianę informacji w ramach interoperacyjności, jednolitej bazy danych terenu, bazy obiektów modeli symulacyjnych oraz modeli 3D na potrzeby wizualizacji wybranych zagrożeń o charakterze kryzysowym oraz podmiotów zarządzania kryzysowego.

Wnioski: Na podstawie przeprowadzonych analiz można stwierdzić, że opracowanie niezbędnych standardów oraz wymagań technicznych dotyczących zapewnienia współpracy pomiędzy różnorodnymi środowiskami symulacyjnymi wymaga optymalizacji i rozszerzenia istniejących standardów wymiany informacji oraz modyfikacji oprogramowania zawartego w istniejących symulatorach pod kątem efektywnego wyświetlania również innych środowisk symulacyjnych.
\end{abstract}

Słowa kluczowe: symulacja, integracja, środowisko wirtualne, zarządzanie kryzysowe

Typ artykułu: artykuł przeglądowy

\section{A B S TRACT}

Aim: The aim of this article is to reveal the need for the integration of simulation solutions used in Poland, for training of public administration staff in the area of crisis management, specifically in the area of research and development concerned with the construction of an integrated simulation platform for bodies engaged with crisis management.

Introduction: The concept of creating an integrated computerised system, utilising advanced simulation techniques, and suitably equipped trainers, for the training of staff responsible for national security, is not a fantasy, but a reality and requirement of our times. An understanding of the system content allows for appropriate identification of requirements and recognition of consequences from

Wyższa Szkoła Policji w Szczytnie / Police Academy in Szczytno, Poland; g.gudzbeler@wspol.edu.pl;

2 Autorzy wnieśli równy wkład merytoryczny w powstanie artykułu / The authors contributed equally to this article; 
decisions made at the needs definition stage. This provides an essential compendium of knowledge on the topic, which is particularly useful for entities not involved with simulations on a daily basis, but are planning the construction of similar systems.

A very significant reference is made to the practical aspect of creating integrated simulation systems and the universal application of such solutions. This which may be of interest equally to the academic world and their representatives working on different features of simulation systems as well as for practitioners who wish to achieve desired outcomes quickly through a selection of available solutions in the market place.

Results: The article identified an operational concept for an integrated simulation platform, encompassing organisations engaged with crisis management. It revealed elements, where a facility for the exchange of information plays an important part within parameters of interoperability. These include; unified terrain databases, construction of simulation model databases and 3D models, which satisfy visual needs for identified threats faced by organisations engaged with crisis management situations.

Conclusions: Based on the performed analysis, it is concluded that there is a need to develop necessary standards and technical requirements, among diverse simulation environments, to achieve co-operation between systems. The broadening and optimisation of existing standards, in relation to the exchange of information, and modification of software will facilitate effective blending between diverse simulation systems.

Keywords: simulation, integration, virtual environment, crisis management Type of article: review article

\section{АННОТАЦИЯ}

Цель: Целью настоящей статьи является попытка обратить особое внимание на необходимость стандаризации и объединения решений, принмаемых при обучении сотрудников публичной администрации в сфере управления ЧС, в особенности решений, связанных с исследованиями и разработками на тему создания интегрированной симуляционной системы для субъектов управления ЧС.

Введение: Современные концепции создания интегрированных компьютерных тренажерных систем для подготовки сотрудников служб по охране безопасности, в которых используются технологически продвинутые тренажеры, это не фантазия, а наоборот, они явялются вполне реальными и полностью отвечают современным требованиям. Ознакомление с ними позволяет правильно определить требования и понять последствия решений, принимаемых на этапе определения возникающих в данный момент потребностей. Они явялются своеоборазным источником знаний на эту тему, особенно для субъектов, которые непосредственно не связаны с симуляциями, а могут привлекатся для планирования похожих систем. Очень значимой явялется практическая сторона создания интегрированных симуляционных систем, котороя свидетельствует о их универсальности. Системы могут представлять интерес для многих научных работников и тех, кто занимается созданием разного вида тренажеров-симуляторов, а также для специалистов-практиков, которые намерены в короткий срок достичь соответствующего результата путем использования не совсем отвечающим требованиям клиента доступных на рынке систем. Результаты: В статье представлена концепция работы интегрированной симуляционной системы для субъектов управляющих ЧС с учетом модулей, с помощью которых возможным явялется обмен информацией в рамках взаимодействия, использования единой базы данных о местности, базы определенных объектов-моделей и 3D-моделей с целью визуализации определенных рисков, чрезвычайного характера и субъектов управления ЧС.

Выводы: На основании анализа можно сделать вывод, что развитие необходимых стандартов и технических требований для обеспечения сотрудничества между различными симуляционными средами требует оптимизации и расширения существующих стандартов для обмена информацией и проведения модификации программного обеспечения тренажеров с целью эффективного отображения также другой симуляционной среды.

Ключевые слова: моделирование, объединение систем, виртуальная среда, управление ЧС

Вид статьи: обзорная статья

\section{Wprowadzenie}

Zintegrowana Platforma Symulacyjna Podmiotów Zarządzania Kryzysowego [1] (Platforma) to będące w budowie narzędzie informatyczne, które umożliwi integrację trenażerów wykorzystywanych przez Policję, Państwową Straż Pożarną, Wojsko Polskie oraz inne służby dysponujące systemami symulacyjnymi przeznaczonymi do szkolenia funkcjonariuszy służb państwowych oraz żołnierzy Wojska Polskiego. Platforma pozwoli powiększać potencjał już zintegrowanego systemu, przede wszystkim wspólną, jednolitą bazę danych terenu oraz obiektów, pozwalając prowadzić ćwiczenia o wysokim poziomie realizmu, jednocześnie, w różnych miejscach i przez różne podmioty, przy zachowaniu jednolitej bazy terenu i wzajemnym oddziaływaniu systemu na zachowania ćwiczących. Budowa zintegrowanej platformy symulacyjnej jest pomysłem nowatorskim w obszarze bezpieczeństwa wewnętrznego. Podobne rozwiązania, ale wyłącznie w obszarze obronności, posiadają wiodące w branży symulacyjnej USA i Australia.

W związku z ograniczoną liczbą dostępnych na rynku polskim rozwiązań, które mogą zostać poddane integracji w ramach jednego systemu, pod uwagę wzięto symulatory w chwili obecnej wykorzystywane przez służby odpowiedzialne za bezpieczeństwo, w szczególności za zarządzanie kryzysowe, ratownictwo, a także bezpieczeństwo i porządek publiczny. Baza terenu obejmie obszar uwzględniony w już istniejących symulatorach, jedynych spełniających kryteria integracji, między innymi w symulatorze działań Policji w sytuacjach kryzysowych [2], symulatorze do szkolenia i treningu wspomagającego dowodzenie podczas działań ratowniczych związanych z pożarami w budynkach wielokondygnacyjnych i z wypadkami komunikacyjnymi [3], symulatorze kierowania pojazdami uprzywilejowanymi 
w sytuacjach typowych i ekstremalnych [4], zintegrowanym mobilnym systemie wspomagającym działania antyterrorystyczne i antykryzysowe - „Proteus” [5], a także w innych symulatorach będących w dyspozycji ministerstwa obrony narodowej np. lotu śmigłowcem. Oprogramowanie zintegrowanej platformy symulacyjnej będzie wykonane zgodnie z międzynarodowymi standardami HLA (ang. High Level Architecture). Stworzy to możliwość połączenia siecią komputerową budowanego systemu $\mathrm{z}$ innymi symulatorami działającymi we wspólnym środowisku wirtualnym w ramach interoperacyjności systemów symulacyjnych. Obecnie w Polsce nie stosuje się żadnego standardu umożliwiającego działanie istniejących systemów symulacyjnych w ramach federacji. HLA jest ogólną architekturą dla rozproszonych systemów komputerowych, ze szczególnym uwzględnieniem systemów symulacyjnych. Ideą HLA jest, aby aplikacje programowe (symulatory komputerowe) mogły porozumiewać się między sobą niezależnie od tego, na jakiej platformie zostały osadzone. Komunikacją pomiędzy poszczególnymi aplikacjami zajmuje się infrastruktura uruchomieniowa - RTI (ang. Runtime Infrastructure), która pełni rolę podobną do usług systemu operacyjnego lub funkcji maszyny wirtualnej i zapewnia interoperacyjność powiązanych symulatorów, możliwość wielokrotnego wykorzystania elementów systemów symulacyjnych, rozdzielenie warstw elementów symulacyjnych i warstwy elementów pomocniczych środowiska [6]. W ramach HLA wykorzystuje się DIS (ang. Distributed Interface Simulation) - interfejs rozproszonej symulacji, czyli protokół umożliwiający prowadzenie ćwiczeń w czasie rzeczywistym, definiujący standardowe struktury komunikatów oraz reguły ich wymiany (IEEE 1278-1993). Efektem końcowym projektu ma być opracowanie zintegrowanej platformy symulacyjnej podmiotów zarządzania kryzysowego umożliwiającej symulację sytuacji kryzysowych oraz prowadzenia w tych warunkach działań antykryzysowych przez uprawnione podmioty (Policję, Państwową Straż Pożarną, Wojsko Polskie, Biuro Ochrony Rządu, a w przyszłości również przez Straż Miejską i inne służby miejskie, Straż Graniczną, zespoły Ratownictwa Medycznego, Żandarmerię Wojskową oraz Służbę Więzienną). Możliwość integracji działań tak wielu zróżnicowanych służb, a jednocześnie znacząco różniących się środowisk działań oraz różnorodności warunków wpływających na pomyślne wykonanie postawionych zadań wymaga, aby proponowane rozwiązanie było wydajne, niezawodne, a przede wszystkim skalowalne, przy czym musi w maksymalnym stopniu korzystać ze standardów komunikacyjnych stosowanych w aktualnej technologii informatycznej, co ułatwi w przyszłości symulację wspólnych działań ze służbami innych krajów europejskich oraz spoza naszego kontynentu.

Tak postawione zadanie wymaga opracowania szczegółowych wymagań technicznych, a następnie znalezienia szczegółowych rozwiązań przede wszystkim w trzech obszarach, tj. warstwy transmisyjnej oprogramowania umożliwiającej współdziałanie różnych symulatorów w jednej przestrzeni wirtualnej (ang. virtual reality), bazy danych terenu oraz bazy obiektów i warstwy informacyjnej dla modeli „sztucznej inteligencji” (ang. artificial intelligence) zapewniającej odpowiednie zachowanie się wszystkich uczestników wirtualnej rzeczywistości. Warstwa transmisyjna będzie opracowana w oparciu o międzynarodowy standard HLA, który jest powszechnie stosowany w symulatorach lotniczych. Będzie można wykorzystać wieloletnie doświadczenia wynikające ze stosowania tego standardu, gdzie komunikacja ze wszystkimi symulatorami lotniczymi będzie zapewniona „automatycznie”. Trzeba zdawać sobie sprawę z tego, że standard ten nie jest optymalizowany pod kątem symulacji specyficznych działań lądowych. Stąd też nowa warstwa transmisyjna będzie wymagała opracowania modułów komunikacyjnych dla każdego z istniejących symulatorów, które będą potrafiły przełożyć informacje specyficzne dla każdego z symulatorów na standard HLA (a właściwie - jego rozszerzenie) i wysłać je do pozostałych symulatorów - federatów, a jednocześnie odfiltrować ze wszystkich informacji niesionych tych standardem te, które są istotne z punktu widzenia każdego z symulatorów. Podobna sytuacja ma miejsce $z$ bazami terenu i obiektów. W każdym z symulatorów istnieje baza danych terenu i obiektów na tyle szczegółowa, na ile jest to istotne dla szkolenia prowadzonego na danym symulatorze. Prowadzenie działań w czasie rzeczywistym (ang. real time) wymaga optymalizacji z punktu widzenia każdego symulatora, co oznacza, że nawet ten sam teren i te same obiekty będą miały inną reprezentację $\mathrm{w}$ każdym $\mathrm{z}$ symulatorów. To przetworzenie wymaga opracowania odpowiednich standardów i reguł, a w miarę możliwości - opracowania zautomatyzowanego procesu przetwarzania wspólnej bazy w postać optymalną.

W celu opracowania spójnego środowiska wirtualnego przeprowadzono badania baz danych wymienionych rozwiązań symulacyjnych.

\section{Charakterystyka integrowanych baz danych}

Baza środowiska wirtualnego symulatora działań Policji w sytuacjach kryzysowych obejmuje wybrany obszar Warszawy uwzględniający centrum miasta, a szczególnie obiekty ważne dla bezpieczeństwa publicznego oraz istotne ze względu na realizację działań w zakresie akcji i operacji policyjnych. Wirtualne środowisko oparte zostało o fragment rzeczywistego miasta. Wszystkie elementy środowiska, które mają wpływ na realizm odbieranej informacji, zostały przedstawione z zastosowaniem modelowania 3D. Modelowane elementy są łatwo rozpoznawalne i identyfikowalne dla ćwiczących. Zostały zobrazowane budynki z zewnątrz, elementy krajobrazu, roślinności, zasoby policji i służb współdziałających, pojazdy cywilne, ludność cywilna, tłumy, ciągi komunikacyjne, parki oraz inne standardowe charakterystyczne elementy miasta. Modelowane są także różnorodne zjawiska atmosferyczne oraz zmiany elementów w czasie symulacji - budynki mogą ulegać zniszczeniu, tłumy zmieniać swoją gęstość, zachowanie i wygląd, zależnie od zadanej sytuacji. Szczególnie dokładnie zobrazowane są charakterystyczne budynki: Stadionu Narodowego, Sejmu oraz Dworca Centralnego wraz z wnętrzami. Modelowane są również stany zachowań ludzkich w taki sposób, aby sytuacja w systemie była jak najbardziej zbliżona do realnej, jednocześnie możliwa do ocenienia przez osoby ćwiczące.

Zobrazowanie terenu środowiska wirtualnego symulatora działań Policji w sytuacjach kryzysowych podzielone 
jest na trzy poziomy szczegółowości. Obszar o wysokiej szczegółowości obejmuje bezpośrednie okolice (w promieniu około $500 \mathrm{~m}$ ) od miejsc prowadzonych działań policyjnych. Obszar o średniej szczegółowości obejmuje teren położony w dalszej odległości od miejsca możliwych działań policyjnych (powyżej 500 m). Natomiast obszar o niskiej szczegółowości obejmuje pozostałe części miasta. Cechy zobrazowania obszaru o wysokiej szczegółowości zawierają takie elementy jak pełna siatka ulic i pieszych ciągów komunikacyjnych, ulice z krawężnikami i elementy małej architektury miejskiej (latarnie, słupy, kosze, ławki), a także infrastruktura budowlana o charakterze odpowiadającym rzeczywistej zabudowie. Budynki mają uproszczoną geometrię, a ich specyficzna architektura jest odwzorowana za pomocą tekstur. Charakterystyczne budynki i obiekty specyficzne dla danej okolicy są zamodelowane z zachowaniem wierności geometrii i wyglądu elewacji. Obszar o średniej szczegółowości posiada pełną siatkę ulic, uproszczoną siatkę pieszych ciągów komunikacyjnych, ulice z krawężnikami i uproszczoną zabudowę. Budynki mają gabaryty zbliżone do rzeczywistych, a do modelowania zastosowano tekstury oddające charakter zabudowy. W ramach obszaru o średniej szczegółowości wnętrza budynków nie są odwzorowane. Obszar o niskiej szczegółowości charakteryzuje się znacznie uproszczonymi cechami zobrazowania polegającymi na zamodelowaniu ich za pomocą płaskiej tekstury terenu oraz w postaci charakterystycznych wysokich budynków i obiektów, które mogą być widoczne z obszarów o wysokim i średnim stopniu szczegółowości. Na potrzeby przemieszczania sił policyjnych baza obszaru o niskiej szczegółowości zawiera także informację o siatce głównych dróg dojazdowych do obszaru o średniej szczegółowości wraz z przepustowością tych dróg.

Baza terenu to spójny obszar Warszawy. Wewnątrz tego obszaru znajduje się teren o średniej szczegółowości, w którym z kolei występują cztery bazy terenu o wysokiej szczegółowości wykonane na potrzeby zaplanowanych scenariuszy ćwiczeń: „Stadion”, „Stare Miasto”, „Dworzec”, „Sejm”. Baza „Stadion” obejmuje Stadion Narodowy wraz z okolicznymi mostami i stacją kolejową Stadion. W otoczeniu stadionu zamodelowano budynki zgodnie ze stanem zabudowy na rok 2012. Baza danych terenu może zostać uaktualniona, w przypadku gdy to okaże się konieczne. Stadion Narodowy został zamodelowany zarówno z zewnątrz, jak i wewnątrz. Na potrzeby symulacji zamodelowano wejścia i wjazdy do stadionu wykorzystywane w trakcie imprez masowych organizowanych na stadionie. Budynek dworca kolejowego Stadion został zamodelowany z zewnątrz, a perony dworca zamodelowano w sposób uproszczony. W bazie „Stare Miasto” wykonano model Starówki, Placu Zamkowego oraz ulicy Krakowskie Przedmieście. W bazie tej zamodelowane zostały dodatkowo przejścia pomiędzy budynkami lub przez budynki istotne $\mathrm{z}$ punktu widzenia prowadzenia działań policyjnych. W skład bazy „Dworzec” wchodzi budynek Dworca Centralnego oraz okolice Pałacu Kultury i Nauki. Dworzec Centralny zamodelowano wraz z wnętrzem hali głównej oraz podziemnymi przejściami. Wnętrza Dworca Centralnego i podziemne przejścia zamodelowane zostały w sposób uproszczony uwzględniający ich geometrię i ogólną kolorystykę. Pałac Kultury i Nauki oraz budynek centrum handlowego Złote Tarasy zamodelowano wyłącznie z zewnątrz. Wykonano także modele podziemnego przejścia z Dworca Centralnego do Dworca Śródmieście oraz wyjścia na ulicę Al. Jerozolimskie. Baza „Sejm” obejmuje budynek Sejmu RP wraz z terenem przyległym. Budynek Sejmu został zamodelowany z uproszczonym wnętrzem, a wybrane pomieszczenia odwzorowano z większą szczegółowością. Możliwe jest modyfikowanie bazy terenu poprzez zmianę wyglądu wybranych budynków (w danej szczególnej lokalizacji możliwe jest wybranie jednego z np. trzech różnych budynków), a także tworzenie sztucznych przeszkód dla ruchu ludzi i pojazdu takich jak np. przegrodzenie ulicy płotem (teren budowy).
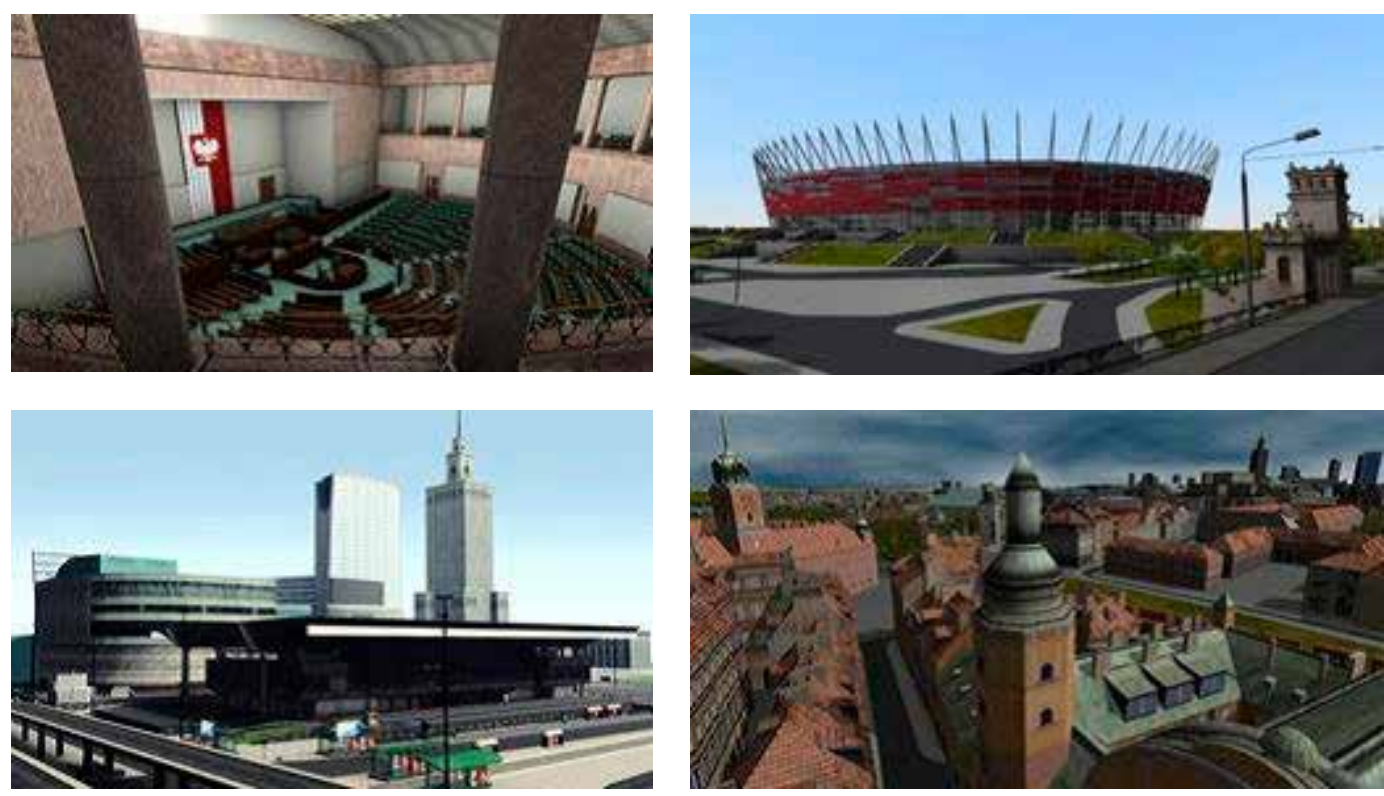

Ryc. 1. Obraz systemu przedstawiający rzeczywistość wirtualną

Fig. 1. An image depicting virtual reality

Źródło: Dane uzyskane z symulatora działań Policji w sytuacjach kryzysowych.

Source: Data obtained from a simulator of Police activities during crisis incidents. 
Następną bazę środowiska wirtualnego stanowi symulator do szkolenia i treningu wspomagającego dowodzenie podczas działań ratowniczych związanych z pożarami w budynkach wielokondygnacyjnych i wypadkami komunikacyjnymi. Dla ćwiczeń realizowanych według scenariusza RTA (zdarzenie drogowe), baza terenu wirtualnego środowiska obejmuje rondo w Glinojecku oraz ulice dojazdowe do niego na długości $200 \mathrm{~m}$ w każdą stronę (ryc. 2). Granica obszaru wykonana została w taki sposób, aby zapewnić wrażenie istnienia dalszego otoczenia.

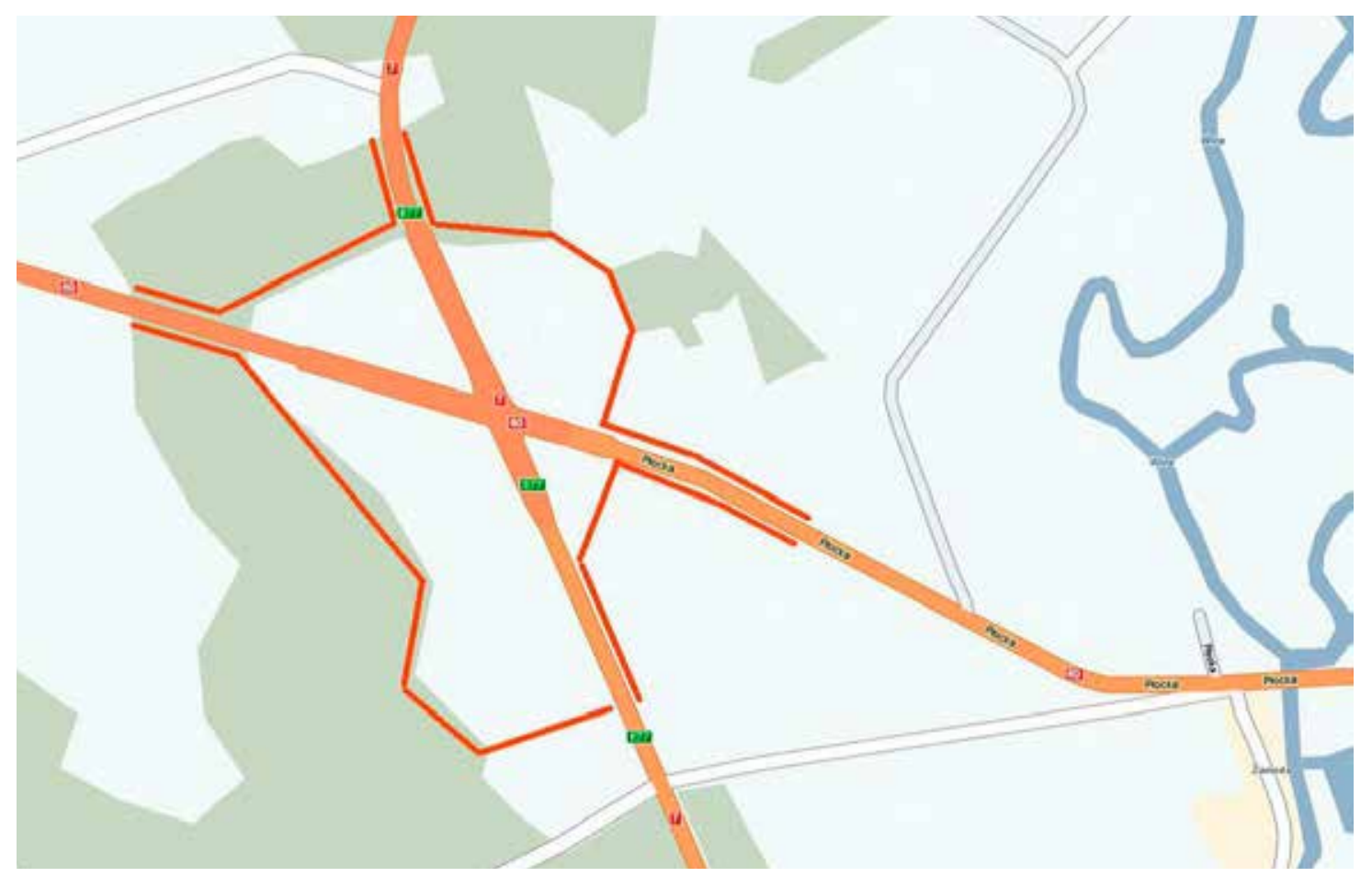

Ryc. 2. Mapa ronda w Glinojecku

Fig. 2. Map of Glinojeck roundabout

Źródło: Dane uzyskane z symulatora do szkolenia i treningu wspomagającego dowodzenie podczas działań ratowniczych związanych z pożarami w budynkach wielokondygnacyjnych i wypadkami komunikacyjnymi.

Source: The data obtained from the simulator for training and supporting leadership training during fire rescue operations in multi-storey buildings and traffic accidents.

Dla ćwiczeń realizowanych według scenariusza MPB (budynek wielofunkcyjny) baza terenu obejmuje obszar ograniczony czterema ulicami, wewnątrz którego znajduje się budynek wielofunkcyjny, w którym prowadzona jest akcja ratownicza. Poza tym kwartałem zostały zobrazowane najbliższe obiekty (pierwszy rząd domów). Dalsza zabudowa została odzwierciedlona w sposób uproszczony, zapewniający wrażenie prowadzenia akcji w warunkach miejskich. Do ćwiczeń w szpitalu, hotelu, bloku mieszkalnym została wykonana baza zawierająca ten sam teren (podkład geometryczny i budynki w otoczeniu) oraz jeden budynek będący obiektem symulacji „szpital”, „hotel”, „blok”. W każdej z baz gabaryty budynku są takie same. Różne są jego wnętrza oraz elewacja. Dla wnętrza każdego budynku zamodelowano parter oraz jedno piętro, które może być powielane w pionie. Elewacje zostały wykonane w taki sposób, aby jednoznacznie wskazywały na charakter budynku (inne malowanie, napisy typu „hotel”, „szpital”). Bezpośrednie otoczenie budynku jest różne także w każdej z baz. Przy użyciu elementów małej architektury takich jak drzewa, krzewy, żywopłoty, kwietniki, ławki oddano charakter otoczenia każdego z typów budynków (ryc. 3).

Kolejna zakwalifikowana do integracji baza środowiska wirtualnego dotyczy symulatora kierowania pojazdami uprzywilejowanymi w sytuacjach typowych i ekstremalnych. Baza ta została zbudowana zgodnie $\mathrm{z}$ wymaganiami zawartymi w rozporządzeniu Ministra Infrastruktury z dnia 8 kwietnia 2011 r. w sprawie urządzenia do symulowania jazdy w warunkach specjalnych (Dz.U. Nr 81, poz. 444). Środowisko wirtualne symulatora w możliwie wysokim stopniu wizualizuje elementy środowiska realnego. Teren otaczający pokonywaną drogę ma naturalne pokrycie oraz typową zabudowę i infrastrukturę drogową. Odwzorowywany teren obejmuje obszary niezabudowane oraz obszary zabudowane, wiejskie i miejskie. Obszary zabudowane charakteryzują się zróżnicowaną intensywnością zabudowy. Charakterystyka wizualizowanego terenu jest bardzo zróżnicowana i zawiera tereny: bez nachyleń, z niewielkimi nachyleniami i typowy dla obszarów górskich. W bazie danych terenu znajdują się wybrane rodzaje dróg, w tym drogi ekspresowe, o charakterystyce autostrad, drogi jedno- i dwujezdniowe, a także $\mathrm{z}$ nawierzchnią utwardzoną i nieutwardzoną. Nachylenie na zaimplementowanych drogach jest odpowiednio zróżnicowane i zawiera: podjazdy i zjazdy o dużym nachyleniu, o zmiennym nachyleniu oraz serpentyny. Zaznaczyć należy, że symulowane drogi zawierają wszystkie elementy dróg rzeczywistych odwzorowane zgodnie $z$ warunkami określonymi w obowiązującej 
w Polsce ustawie z dnia 25 marca o drogach publicznych (Dz.U. Nr 14, poz. 60) wraz z innymi obowiązującymi przepisami wykonawczymi, takie jak oznaczenia zarówno poziome, jak i pionowe, chodniki, skrzyżowania i trasy dla pojazdów szynowych. Długość tras jazdy w systemie przekracza $300 \mathrm{~km}$. Długość tras umożliwia ciągłą jazdę przez około 8 godzin. Występują także różnorodne elementy infrastruktury drogowej takie jak: skrzyżowania dróg
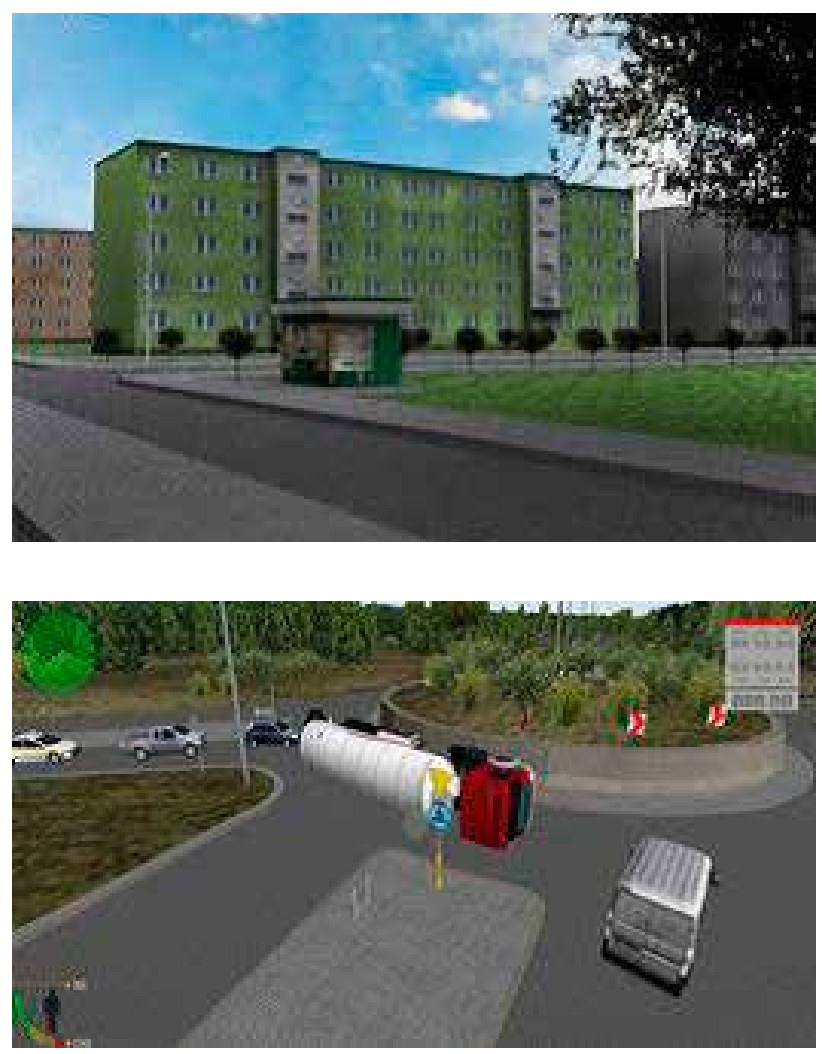

różnego typu, węzły drogowe, wiadukty, mosty, tunele, przejścia dla pieszych, przystanki autobusowe i parkingi. Ponadto symulowane jest zachowanie innych uczestników ruchu drogowego, tj. pojazdów samochodowych (uprzywilejowanych, osobowych, ciężarowych, ciągników siodłowych, specjalnych, ciągników rolniczych, autobusów oraz motocykli), pojazdów szynowych oraz pieszych, motocyklistów i rowerzystów.
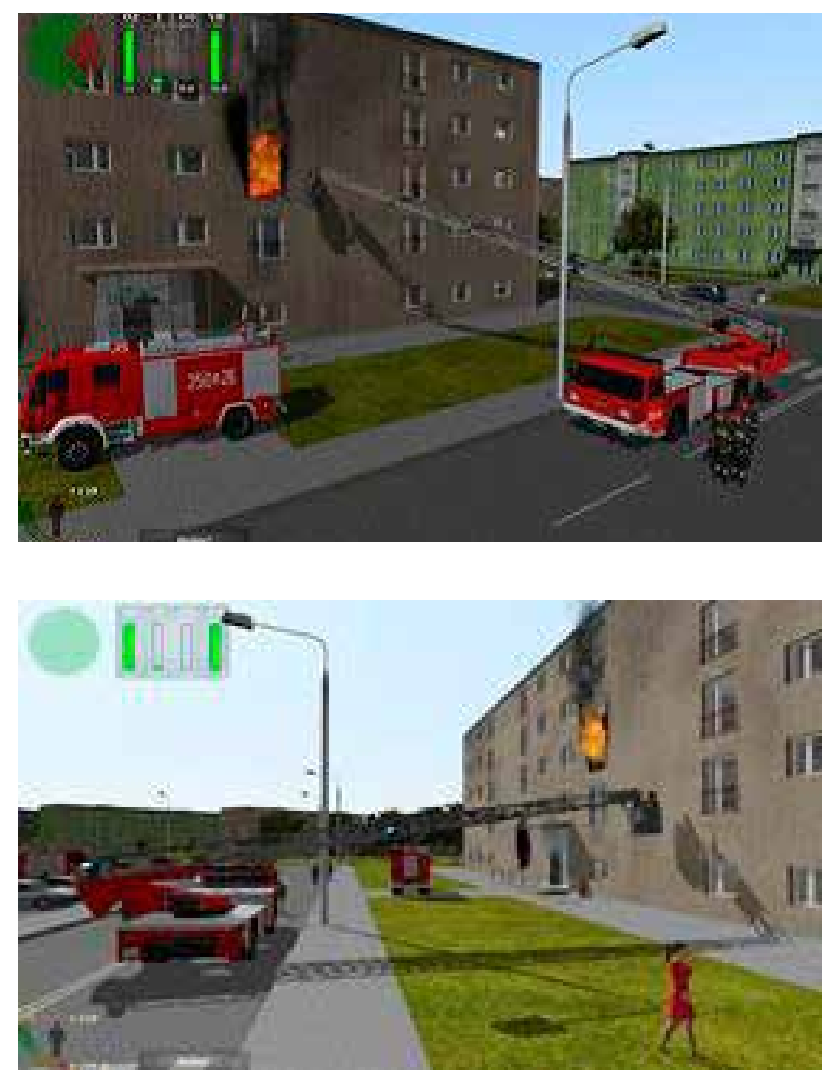

Ryc. 3. Fragment bazy terenu

Fig. 3. Terrain fragment

Źródło: Dane uzyskane z symulatora do szkolenia i treningu wspomagającego dowodzenie podczas działań ratowniczych związanych z pożarami w budynkach wielokondygnacyjnych i wypadkami komunikacyjnymi.

Source: The data obtained from the simulator for training and supporting leadership training during fire rescue operations in multi-storey buildings and traffic accidents.

Oprogramowanie symulatora umożliwia symulację i wizualizację 25 pojazdów uczestniczących w ruchu drogowym znajdujących się w polu widzenia kierowcy. Pojazdy i piesi, którzy uczestniczą w ruchu drogowym, mogą postępować zgodnie lub niezgodnie z zasadami ruchu drogowego. W systemie mogą być symulowane standardowe zjawiska występujące $\mathrm{w}$ trakcie jazdy związane np. $\mathrm{z}$ natężeniem ruchu. Zachowanie uczestników ruchu drogowego zależy od bieżącej sytuacji i regulowane jest zastosowanymi modelami symulacyjnymi oraz skryptami zawartymi w systemie, ich reakcje są następstwem działań innych uczestników ruchu drogowego, w tym pojazdu ćwiczącego $\mathrm{z}$ wykorzystaniem systemu kierowcy. W systemie uwzględniono możliwość modyfikacji zarówno pór roku, ich charakterystyki (opady deszczu, śniegu itp.), pory doby z realnymi zmianami wynikającymi z upływającego czasu. System umożliwia instruktorowi dokonanie zmian w każdym elemencie związanym $z$ warunkami pogodowymi, a także generowanie jako podgrywek takich zjawisk jak powodzie, zamglenia, oblodzenia itd. Symulowane czynniki pogodowe są zgodne ze swoimi rzeczywistymi odpowiednikami, z uwzględnieniem ich wpływu na pozostałe elementy systemu. Drogi w terenie zabudowanym są oświetlone. Oświetlenie symulowanych pojazdów odpowiada obowiązującym przepisom.

Kolejna baza środowiska wirtualnego dotyczy symulatora śmigłowca. To otoczenie, w którym operuje śmigłowiec - teren ok. 100 x 100 km wzorowany na bazie wojskowej Randalph AFB Texas, zawierający między innymi bazę wojskową z lotniskiem. Dane nawigacyjne zostały oparte o dane DAFIF (ang. Digital Aeronautical Flight Information File). Oznacza to, że została uwzględniona symulacja ILS (ang. Instrumental Landing System), VOR (ang. VHF Omnidirectional Range), NDB (ang. Non-Directional Beacon), świateł lotnisk i lądowisk - światła podejścia, światła pasa, FATO (ang. Final Approach and Takeoff Area). Ponadto baza odwzorowuje fragment geoidy co najmniej 1 x 1 stopień, 
zawiera różne rodzaje terenu (m.in. ocean, teren górski, jeziora, różne typy upraw, lasy, obszary miejskie z charakterystyczną dla nich zabudową (budynki mieszkalne, fabryki, biura itd.), odwzorowane zostały także drogi, wiadukty, tunele, linie kolejowe, sieci energetyczne).

Kolejną proponowaną do integracji bazą jest środowisko wirtualne robota pirotechnicznego - Proteus. Obejmuje ono teren o wymiarach $200 \times 200 \mathrm{~m}$. Mapa terenu otoczenia treningowego zawiera zróżnicowane pofałdowanie terenu oraz różne rodzaje podłoża - pagórki, drogi, doły oraz rowy rozmieszczone w różnych miejscach. Środowisko wirtualne uwzględnia teren naturalny (trawa niska, trawa wysoka od 450-600 mm), błoto, brzeg jeziora (granica między brzegiem a wodą), obszar zamarznięty (lód), teren miejski, teren $\mathrm{z}$ losowo rozrzuconymi kamieniami o różnorodnym kształcie i rozmiarze (w przybliżeniu średnice kamieni - 150, 200, 250, $300 \mathrm{~mm}$ ). Ponadto teren określony jako tor przeszkód, w którym występuje droga z wybojami (otwory w drodze o średnicy około $300 \mathrm{~mm}$ i głębokości $150 \mathrm{~mm}$, wysokość podjazdów wynosi $300 \mathrm{~mm}$, a kąt nachylenia podjazdu 30 stopni), dodatkowo przy drodze znajduje się chodnik, płyty chodnikowe, krawężniki (od 15 do $20 \mathrm{~cm}$ ). To również różne rodzaje drzew, krzewy o różnej przejrzystości (aby robot mógł przez nie przejechać), ścięte drzewo (przewrócone), prześwit o wielkości prostokąta 1000 x $800 \mathrm{~mm}$ i średnicy drzewa $400 \mathrm{~mm}$. Dopełnieniem jest budynek jednopiętrowy o rozmiarach ok. $6 \times 10 \mathrm{~m}$, taras $-6 \times 3 \mathrm{~m}$, składający się z dwóch pokoi, łazienki i tarasu.

\section{Spójne środowisko wirtualne}

Wykonanie bazy danych platformy symulacyjnej podmiotów zarządzania kryzysowego wiąże się z procesem przygotowania danych dla konkretnych zastosowań. W symulatorach najczęściej są to dane dla silnika fizyki lub silników sztucznej inteligencji. W tym przypadku to silnik sztucznej inteligencji automatycznego ruchu drogowego, silnik fizyki, silnik poruszania się ludzi i pojazdów AI Implant, a także silnik zachowań tłumu. Przyjęto, że platforma powinna umożliwiać przeprowadzenie złożonych symulacji zdarzeń z udziałem policji, straży pożarnej, nawigację śmigłowca i quadrotora, poruszanie się robotem opartym na autonomicznym modelu matematycznym wykorzystującym środowisko MRDS (ang. Microsoft Robotic Developer Studio), poruszanie się samochodem oraz ruch automatyczny elementów środowiska (piesi, samochody itp.).

Analiza poszczególnych baz danych wskazuje, że w każdym symulatorze używana jest inna baza danych terenu. W symulatorach lotniczych domyślnie używany jest układ WGS 84 (ang. World Geodetic System '84), w lądowych - kartezjański. Możliwe jest przeliczanie współrzędnych między obydwoma układami. W przypadku bazy danych terenu przeliczenie wystarczy zrobić tylko raz. Przy małych odległościach możliwe jest pominięcie przeliczenia przez potraktowanie rozbieżności między układami jako błędu. Natomiast przy rozmiarach bazy typu $40 \mathrm{~km}$ rozbieżności mogą sięgać kilku metrów. Wszystkie projekty bazują na silniku OSG (ang. OpenSceneGraph). Dzięki temu ułatwione jest renderowanie modeli z jednego systemu w drugim. Występują jednak często drobne rozbieżności i należy założyć, że potrzebne będzie wykonanie czynności adaptacyjnych, gdyż każdy z systemów używa innego silnika logiki i fizyki. W pewnych przypadkach niezbędne jest odczytywanie kolizji z wizualizacji. Zdecydowana większość modeli 3D jest przygotowywana w 3D Studio Max, a następnie eksportowana do formatów OSG. Każdy $\mathrm{z}$ takich modeli ma swoją specyfikę podyktowaną docelowym wykorzystaniem w symulatorze. W analizowanych symulatorach używane są wspólne i uproszczone silniki animacji, a także animowane są pojedyncze obiekty w oparciu o uproszczony silnik animacji OSG. Podobnie możliwości renderowania wielu dynamicznych obiektów są różne, gdyż nie we wszystkich symulatorach zaimplementowany został wydajny mechanizm renderowania wielu dynamicznych obiektów, w tym renderowanie tłumów nawet powyżej 500 osób. Niestety są i takie, gdzie renderowane są zaledwie pojedyncze obiekty. Taki stan rzeczy powoduje konieczność dostosowania do renderowania wielu obiektów, bądź renderowania ich w uproszczony sposób. W związku z dużą złożonością obliczeniową przecięć z terenem, czyli powierzchni, po której poruszają się pojedyncze osoby w tłumie, konieczna jest bardzo wydajna struktura danych. Wymaga to przygotowania danych w specyficznej formie, a proces ten musi być w dużej mierze zautomatyzowany.

W każdym $z$ symulatorów istnieje baza danych terenu i obiektów na tyle szczegółowa, na ile jest to istotne z punktu widzenia szkolenia prowadzonego na danym symulatorze. Prowadzenie działań w czasie rzeczywistym (ang. real time) wymaga optymalizacji z punktu widzenia każdego symulatora, co oznacza, że nawet ten sam teren i te same obiekty będą miały inną reprezentację w każdym $\mathrm{z}$ symulatorów. To przetworzenie wymaga opracowania odpowiednich standardów i regul, a w miarę możliwości - opracowania zautomatyzowanego procesu przetwarzania wspólnej bazy w postać optymalną z punktu widzenia danego symulatora.

Podobne mechanizmy powinny być zastosowane w przypadku warstwy zapewniającej inteligentne zachowanie się wszystkich uczestników symulowanej wirtualnej rzeczywistości (zwłaszcza w symulatorach obiektów bojowych - polem walki). Zgodnie z zasadami symulacji rozproszonej poszczególne elementy tworzonego systemu staną się integralnymi częściami łączonych systemów w ramach ogólnopolskiej zintegrowanej platformy symulacyjnej. Ze względu na liczbę łączonych federatów znajdujących się w Wyższej Szkole Policji w Szczytnie (symulator działań Policji w sytuacjach kryzysowych oraz symulator kierowania pojazdami uprzywilejowanymi w sytuacjach typowych i ekstremalnych) centrum techniczne, logistyczne i administracyjne zostanie umieszczone w siedzibie lidera konsorcjum naukowo-przemysłowego, czyli Wyższej Szkoły Policji w Szczytnie.

\section{Wnioski}

Obecnie nie ma na rynku systemu, który w sposób kompleksowy zapewniałby wspólny trening różnych podmiotów odpowiedzialnych za zarządzanie w sytuacjach kryzysowych. Opracowanie ogólnopolskiej zintegrowanej platformy stanowi niezwykle istotne uzupełnienie prowadzonych 
obecnie szkoleń (szczególnie z zakresu interoperacyjności). Przyczyni się to nie tylko do poprawy efektywności szkoleń (poprzez zobiektywizowanie oceny oraz możliwość odtwarzania i analizy przeprowadzonych ćwiczeń - tzw. After Action Review), znacznego zmniejszenia zagrożeń i poprawy bezpieczeństwa osób uczestniczących w ćwiczeniach, ale przede wszystkim do znaczącego obniżenia kosztów szkoleń i ich szkodliwego wpływu na środowisko.

Drugim istotnym aspektem jest opracowanie niezbędnych standardów oraz wymagań technicznych dotyczących zapewnienia współpracy pomiędzy różnorodnymi środowiskami symulacyjnymi. Z jednej strony wymaga to optymalizacji i rozszerzenia istniejących standardów wymiany informacji (np. HLA), z drugiej strony - do modyfikacji oprogramowania zawartego $\mathrm{w}$ istniejących symulatorach (optymalizowanego pod kątem niezbędnej funkcjonalności i zastosowań danego symulatora) pod kątem efektywnego wyświetlania również innych środowisk symulacyjnych. Zawarcie we wspólnej, jednolitej bazie terenu zróżnicowanych baz danych, a jednocześnie zapewnienie możliwości zobrazowania tego środowiska wirtualnego w każdym z symulatorów (zawierających w tym celu różne, dostosowane dla danego symulatora silniki graficzne, tzw. graphic engines), nie doczekało się, jak dotychczas, satysfakcjonującego rozwiązania.

\section{Podsumowanie}

W artykule przedstawiono pierwszy etap prac badawczych uwzgledniający bazę integrowanego środowiska wirtualnego oraz podstawowe wymagania funkcjonalne zintegrowanej platformy symulacyjnej podmiotów zarządzania kryzysowego. W ramach tego etapu zostały ustalone niezbędne wymagania funkcjonalne dla budowy platformy ze strony podmiotów zarządzania kryzysowego. Równolegle przeprowadzono weryfikację spójności baz danych terenu, baz modeli 3D oraz animacji stosowanych w poszczególnych symulatorach. Na podstawie wymienionych działań zostały opracowane główne założenia projektowe i wymagania techniczne, założenia dla spójnego wirtualnego środowiska, dla wizualizacji oraz sztucznej inteligencji. Zdefiniowany został zakres funkcjonalności nowych modułów oprogramowania oraz niezbędnej modyfikacji istniejących modułów oprogramowania. Również określone zostały scenariusze wybranych zagrożeń o charakterze kryzysowym, które będą implementowane i testowane w poszczególnych zadaniach projektu. Reasumując, przygotowana została koncepcja funkcjonowania zintegrowanej platformy symulacyjnej podmiotów zarządzania kryzysowego z uwzględnieniem modułów umożliwiających wymianę informacji w ramach interoperacyjności, jednolitej bazy danych terenu, bazy obiektów modeli symulacyjnych oraz modeli 3D na potrzeby wizualizacji wybranych zagrożeń o charakterze kryzysowym oraz podmiotów zarządzania kryzysowego.

Artykuł został opracowany w ramach projektu pt. „Zintegrowana Platforma Symulacyjna Podmiotów Zarządzania Kryzysowego" nr DOBR-BIO4/041/13177/2013 finansowanego przez Narodowe Centrum Badań i Rozwoju w Warszawie.

\section{Literatura}

[1] Projekt rozwojowy pt. „Zintegrowana Platforma Symulacyjna Podmiotów Zarzadzania Kryzysowego", nr DOBR-BIO4/041/13177/2013.

[2] Projekt rozwojowy pt. „Budowa prototypu symulatora działań Policji w sytuacjach kryzysowych", nr OR00004107.

[3] Projekt rozwojowy pt. „Opracowanie i wdrożenie symulatora do szkolenia i treningu wspomagającego dowodzenie podczas działań ratowniczych związanych z pożarami w budynkach wielokondygnacyjnych i wypadkami komunikacyjnymi", nr OR00007607.
[4] Projekt rozwojowy pt. „Symulator kierowania pojazdami uprzywilejowanymi podczas działań typowych i ekstremalnych", nr O ROB 0011 01/ID/11/1.

[5] Projekt „Proteus” zrealizowany w ramach Programu Operacyjnego Innowacyjna Gospodarka na lata 2007-2013, poddziałanie 1.1.2: Strategiczne programy badań naukowych i prac rozwojowych, nr umowy: POIG.01.02.01-00-014/08.

[6] http://pl.wikipedia.org/wiki/High_Level_Architecture, [dostęp: 08.06.2015].

podinsp. dr Grzegorz Gudzbeler - dyrektor Instytutu Koordynacji Badań i Funduszy Pomocowych Wyższej Szkoły Policji w Szczytnie.

podinsp. dr Mariusz Nepelski - adiunkt Zakładu Zarządzania Kryzysowego Instytutu Bezpieczeństwa i Porządku Publicznego Wydziału Bezpieczeństwa Wewnętrznego Wyższej Szkoły Policji w Szczytnie. 